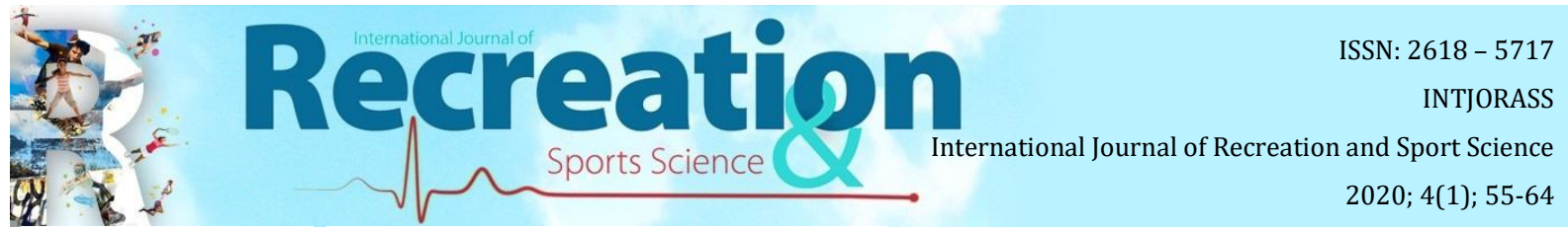

Research Article - https://doi.org/10.46463/ijrss.787026

\title{
Investigation of Physical Appearance Perfectionism and Social- Physical Anxiety in College Students
}

\author{
Fatma ÇEPİKKURT ${ }^{1} \quad$ Yağmur Seda AYAZ ${ }^{2}$ Elif Nilay $\mathrm{ADA}^{3}$ \\ Esen KIZILDAĞ KALE ${ }^{4}$
}

\begin{abstract}
This study aimed to compare the physical appearance perfectionism and social physique anxiety scores of university students with respect to different variables and to reveal the relationship between these variables. The study group, which was selected through convenience sampling, consisted of 191 university students, 111 women $\left(\mathrm{X}_{\mathrm{age}}=20.59\right)$ and 80 men $\left(\mathrm{X}_{\mathrm{age}}=21.39\right)$. This cross-sectional study was planned as a correlational survey model. The "Physical Appearance Perfectionism Scale", and "Social Physique Anxiety Scale" were used as data collection tools. Data were analyzed using descriptive statistics and t-test, one-way analysis of variance, and Pearson correlation analyses were performed. The "hope for perfection" subscale of the Physical Appearance Perfectionism Scale and "comfort with appearance" subscale of the Social Physique Anxiety Scale were negatively correlated $(\mathrm{r}=-.31 ; p<.05)$, while the former showed a positive association with the "expectation of negative evaluation" subscale $(\mathrm{r}=.16 ; p<.05)$. The results of the analysis showed that the participants' Physical Appearance Perfectionism and Social Physique Anxiety scores did not differ significantly according to gender or course of study $(p>.05)$. The Physical Appearance Perfectionism scores also showed no significant differences based on exercise habits, although the "comfort with appearance" scores of the participants who exercised were significantly higher $(\mathrm{t}=2.00 ; p<.05)$. Overall, the students who reported an intense striving for perfection were not comfortable with their appearance and expected negative judgment, whereas those engaging in exercise were comfortable with their appearance.
\end{abstract}

Keywords: Physical Apprearance Perfectionism, Social- Physical Anxiety, College Students

\section{Üniversite Öğrencilerinin Fiziksel Görünüş Mükemmeliyetçiliği ve Sosyal- Fizik Kaygılarının İncelenmesi}

$\ddot{O} z$

Bu araştırmanın amacı üniversite öğrencilerinin fiziksel görünüş mükemmeliyetçiliği ve sosyal görünüm kayg1 puanlarını farklı değişkenlere göre karşılaştırmak ve bu iki değişken arasındaki ilişkiyi açığa çıkarmaktır. Araştırmanın çalışma grubunu kolayda ulaşılabilir örnekleme yoluyla seçilen; 111 kadın $\left(X_{\text {yaş }}=20.59\right)$ ve 80 erkek $\left(X_{\text {yaş }}=21.39\right)$ olmak üzere toplam 191 üniversite öğrencisi oluşturmaktadır. Araştırma ilişkisel tarama modelinde planlanmış kesitsel bir araştırmadır. Araştırmada veri toplama araçları olarak "Fiziksel Görünüş Mükemmeliyetçiliği”" ve "Sosyal Fizik Kaygı Envanteri” kullanılmıştır. Veriler; betimsel istatistik yöntemleri, t-testi, tek yönlü varyans analizi ve pearson korelasyon analizi yöntemleriyle test edilmiştir. Araştırmada elde edilen bulgular; Fiziksel Görünüş Mükemmeliyetçiliği'nin "mükemmellik için umut” alt boyutu ile Sosyal Görünüş Kaygısı Ölçeği’nin “görünüm rahatlığı” alt boyutu arasında olumsuz yönde (r=-.31; p<.05), “olumsuz değer beklentisi”" alt boyutu ile de pozitif yönde $(\mathrm{r}=.16 ; \mathrm{p}<.05)$ anlamlı ilişki olduğunu ortaya koymuştur. Analiz sonuçları katılımcıların fiziksel görünüş mükemmeliyetçiliği ve sosyal görünüm kaygı puanlarının cinsiyete ve okudukları bölüme göre farklılaşmadığını göstermiştir ( $>$ > .05). Katılımcıların Fiziksel Görünüş Mükemmeliyetçiliği puanlarının egzersiz yapma durumuna göre farklılaşmadı̆̆ 1 ancak egzersiz yapan katılımcıların "görünüm rahatlığı" puanlarının anlamlı olarak daha yüksek olduğu bulunmuştur $(\mathrm{t}=2.00 ; \mathrm{p}$ > .05). Sonuç olarak; mükemmele ulaşma çabasını yoğun yaşayan öğrencilerin görünümleri konusunda rahat olmadıkları ve olumsuz değerlendirilme beklentisinde oldukları; egzersize katılım gösterenlerin ise görünümleri konusunda rahat oldukları ifade edilebilir.

Anahtar kelimeler: Fiziksel Görünüş Mükemmeliyetçiliği, Sosyal- Fizik Kaygısı, Üniversite Öğrencileri.

${ }^{\mathrm{T}}$ Mersin University, Sports Science Faculty, Mersin, TURKEY. fcepikkurt@hotmail.com https://orcid.org/0000-00029096-2873

${ }^{2}$ Mersin University, Sports Science Faculty, Mersin, TURKEY yagmursedaayaz33@gmail.com https://orcid.org/00000001-7407-0042

${ }^{3}$ Mersin University, Sports Science Faculty, Mersin, TURKEY nilayada@mersin.edu.tr https://orcid.org/0000-0002-88176136

${ }^{4}$ Nisantasi University, School of Physical Education and Sports, Istanbul, TURKEY. esen.kale@nisantasi.edu.tr https://orcid.org/0000-0002-4927-8682 


\section{INTRODUCTION}

Contemporary society attaches great importance to people's physical appearance. On billboards, newspapers, magazines, and television, as well as in movies, on the internet and social media, the idea that "perfect looks" are essential for success, happiness, love, popularity, and professional advancement is prevalent. Society, culture, and social messages contribute to the creation of standards of the ideal body and beauty, according to which individuals then evaluate themselves (Cash, 2002; Pope, Olivardia, Gruber and Borowiecki,1999; Ricciardelli and Mc Cabe, 2004; Thompson and Cafri, 2007; Tiggemann, 2002). Comparing oneself with images and models depicted in mass media, internalizing ideal beauty standards as a way of judging oneself, and believing that this ideal form is critical in determining self-worth can all affect body image (Tiggemann, 2002). A slim figure with balanced facial features constitutes the physical ideal for women, while men should be muscular with broad shoulders, a large upper body, and a flat stomach (Tiggemann, 2002). When many women fail to reach these standards, they may develop eating disorders and negative body perception (Leit et al., 2002), whereas men, on the other hand, tend to resort to the use of anabolic steroids to achieve a more muscular physique (Pope et al. 2000).

In addition to mass media and social media platforms, high levels of perfectionism may also cause people to base their self-esteem on the ideal beauty standard valued in society (Cash, 2002). Perfectionism is expressed as a multidimensional personality structure related to an individual's efforts to achieve flawlessness and a tendency to impose unattainable standards on oneself, while also seeking to avoid mistakes and exhibiting concern regarding negative judgment (Burns, 1980; Frost, Marten, Lahart, and Rosenblate, 1990; Hewitt and Flett, 1991). Perfectionism manifests itself in two different forms, adaptive and maladaptive (Slaney, Rice, Mobley, Trippi, and Ashby, 2001), and has the potential to affect all areas of an individual's life (Hewitt and Flett, 1991). Studies on perfectionism have mentioned that perfectionism is specific to a given field and have advised that as well as general perfectionism, perfectionism in academia, sports (Çepikkurt and Yazgan İnanç, 2012), parenting (Snell, Overbey, and Brewer, 2005), sexuality (Stoeber, Harvey, Almeida, and Lyons, 2013) and physical appearance (Yang and Stoeber, 2012) should also be measured. Physical appearance is also one of the principal areas in which many individuals exhibit perfectionist tendencies. Yang and Stoeber (2012) introduced the concept of physical appearance perfectionism in order to understand individual differences in perfectionism related to physical appearance. Physical appearance perfectionism consists of two main elements: worry about imperfection and hope for perfection. The former describes an individual's desire for high standards. If the individual does not meet these standards, they tend to become depressed, and their concerns that they will be criticized by others may also cause social anxiety. These individuals require the approval of others in order to feel good and place great importance on being considered excellent by others. The hope for perfection dimension includes the setting of standards imposed on individuals by themselves as well as behaviors involving self-criticism and compulsive self-evaluation. This concept can also be defined as an individual's setting high standards for him/herself and striving for perfection.

Social appearance anxiety (SAA) refers to an individual's concerns regarding physical appearance and the judgment of others. SAA may also be defined as social anxiety experienced based on negative body perception (Doğan, 2010). According to Hart, Palyo, Fresco, Holy and Heimberg (2008), social appearance anxiety is a comprehensive concept that includes specific physical features related to the perception of the body such as skin color, face shape, and nose structure, rather than just overall appearance. How individuals perceive their bodies is directly related to their thoughts and feelings related to their appearance. 
In recent studies, maladaptive perfectionism has been found to be associated with body dissatisfaction and social appearance anxiety. For example, Hewitt, Flett, and Ediger (1995) investigated the relationship between perfectionism dimensions and body image, eating disorders, and physical self-perception in their study on female university students. They found that self-perfectionism was associated with anorexia, while social-induced perfectionism was associated with body dissatisfaction and avoidance of social environments. In a study conducted by Donovan, Chew, and Penny (2014) with female university students, the mediating role of body dissatisfaction in the relationship between perfectionism and weight control was tested. The researchers found that body dissatisfaction did not mediate the relationship between body dissatisfaction and these two variables, but that the relationship between perfectionism and bulimic behavior increased with body dissatisfaction. Grammas and Schwartz (2009), in their study involving male university students, reported that socialinduced perfectionism was associated with body dissatisfaction stemming from height, weight, and muscle structure. Sweeney and Fingerhut (2013) found a relationship between maladaptive perfectionism and body dissatisfaction in their study on pregnant women.

As stated in the relevant literature, perfectionism regarding physical appearance, the effort to attain ideal body standards, negative perceptions regarding the body, and concerns about social appearance may negatively affect people's enjoyment of life in general as well as lead to unhealthy eating behaviors. Therefore, investigating perfectionism regarding physical appearance and related anxiety in university students, who represent an important segment of society, is a matter of considerable importance. The aim of the present study was thus to compare the physical appearance perfectionism and social appearance anxiety scores of university students with respect to different variables and to reveal the relationships between the variables.

\section{METHODS}

This is a cross-sectional study planned as a correlational survey model, the objective being to investigate the relationship between university students' physical appearance perfectionism and social appearance anxiety.

Research Population and Sample: The research population was comprised of students enrolled at Mersin University in the 2019-2020 academic year. The study sample was chosen through convenience sampling and consisted of a total of 191 university students, 111 women $\left(X_{\text {age }}=20.59\right)$ and 80 male $\left(X_{\text {age }}=21.39\right)$.

Data Collection Tools: The Physical Appearance Perfectionism Scale (PAPS) was used to measure the perfectionism of the participants regarding their physical appearance, while the Social Physique Anxiety Scale (SPAS) was employed to assess anxiety levels concerning physical appearance.

\section{Physical Appearance Perfectionism Scale} (PAPS): The Physical Appearance Perfectionism Scale was developed by Yang and Stoeber (2012) and adapted for Turkish by Kollayan (2017). The scale, consisting of two subscales, "worry about imperfection" and "hope for perfection", and containing a total of 12 items, is scored using a 5-point Likert-type scale. The Cronbach alpha values calculated by Kollayan (2017) were .90 and .93 for the "worry about imperfection" and "hope for perfection" subscales, respectively. For the present study, the Cronbach alpha values were .82 for the former and .75 for the latter subscale.

Social Physique Anxiety Scale (SPAS): To determine the anxiety level of the participants concerning social appearance, the Social Physique Anxiety Scale, developed by Hart, Leary, and Rejeski (1989) and adapted for Turkish by Mülazımoğlu-Ballı and Aşçı (2006), was used. The scale consists of two subscales, "comfort with appearance" and "expectation of negative evaluation", and a total of 12 items, all scored according to a 5- 
Çepikkurt, F., Ayaz, Y. S., Ada, E. N., Kızıldağ Kale, E. (2020). Investigation of Physical Appearance Perfectionism and Social-Physical Anxiety in College Students. International Journal of Recreation and Sports Science, 4(1), 55-64. Doi.org/10.46463/ijrss.787026

point Likert-type scale. A high score on the Social Physique Anxiety Scale indicates elevated anxiety levels related to an individual's appearance. The internal consistency coefficient values calculated by Mülazımoğlu-Ballı and Aşçı (2006) were .81 for girls and .77 for boys (Mülazımoğlu-Ballı and Aşç1, 2006). The Cronbach alpha value obtained for the present study was .63.

\section{RESULTS}

Prior to analyzing the relationships between the various subscales within the scope of this study, skewness and kurtosis values were examined to determine whether the data exhibited normal distribution. The below table contains the values for normal distribution.

Table 1. Normality Test Results for the Sample Group Participating in the Study

\begin{tabular}{lccccc}
\hline Subscales & $\mathbf{n}$ & $\mathbf{X}$ & SS & Skewness & Kurtosis \\
\hline $\begin{array}{l}\text { Worry about } \\
\text { imperfection }\end{array}$ & 191 & 2.93 & .44 & .483 & 1.203 \\
\hline Hope for perfection & 191 & 2.67 & .51 & -.130 & .572 \\
\hline $\begin{array}{l}\text { Comfort with } \\
\text { appearance }\end{array}$ & 191 & 4.25 & 1.09 & -1.727 & 1.844 \\
\hline $\begin{array}{l}\text { Expectation of negative } \\
\text { evaluation }\end{array}$ & 191 & 2.41 & .76 & -.141 & -.515 \\
\hline
\end{tabular}

The skewness and kurtosis values presented in Table 1 show the values to be within the acceptable limits. Based on the criteria that skewness values should fall between +1 and 1 and kurtosis values between +2 and -1 (Huck, 2008), the values obtained for all subscales occur within the desired range and thus the data are normally distributed.

In order to compare the PAPS and SPAS subscale scores of the participants by gender, a t-test was performed for independent groups, the results of which are presented in Table 2.

Table 2. t-Test Results of Comparing the Participants' PAPS and SPAS Scores according to Gender

\begin{tabular}{|c|c|c|c|c|c|c|}
\hline Subscales & Gender & $\mathbf{n}$ & $\mathbf{X}$ & SS & $\mathbf{t}$ & $p$ \\
\hline \multirow{2}{*}{$\begin{array}{l}\text { Worry about } \\
\text { imperfection }\end{array}$} & Female & 111 & 2.94 & .45 & \multirow{2}{*}{.488} & \multirow{2}{*}{.626} \\
\hline & Male & 80 & 2.91 & .44 & & \\
\hline \multirow{2}{*}{ Hope for perfection } & Female & 111 & 2.67 & .50 & \multirow{2}{*}{-.105} & \multirow{2}{*}{.916} \\
\hline & Male & 80 & 2.68 & .53 & & \\
\hline \multirow{2}{*}{$\begin{array}{l}\text { Comfort with } \\
\text { appearance }\end{array}$} & Female & 111 & 4.27 & 1.10 & \multirow{2}{*}{-.527} & \multirow{2}{*}{.599} \\
\hline & Male & 80 & 4.23 & 1.08 & & \\
\hline \multirow{2}{*}{$\begin{array}{l}\text { Expectation of negative } \\
\text { evaluation }\end{array}$} & Female & 111 & 2.40 & .77 & \multirow{2}{*}{.898} & \multirow{2}{*}{.370} \\
\hline & Male & 80 & 2.42 & .75 & & \\
\hline
\end{tabular}

$p>.05$

T-test analysis results revealed that the Physical Appearance Perfectionism and Social Physique Anxiety scores of the female and male participants did not differ significantly $(p>.05)$.
Pearson product-moment correlation analysis was performed to determine the relationship between the participants' perfectionism regarding their physical appearance, body mass index (BMI), and anxiety concerning 
Çepikkurt, F., Ayaz, Y. S., Ada, E. N., Kızıldağ Kale, E. (2020). Investigation of Physical Appearance Perfectionism and Social-Physical Anxiety in College Students. International Journal of Recreation and Sports Science, 4(1), 55-64. Doi.org/10.46463/ijrss.787026

social appearance. The results are presented

in Table 3.

Table 3. Results of Correlation Analysis of the Relationship Between Participants' Physical Appearance Perfectionism and Social Physique Anxiety Scores

\begin{tabular}{|c|c|c|c|c|c|c|c|}
\hline Variables & $\begin{array}{l}\text { Comfort with } \\
\text { appearance }\end{array}$ & \multicolumn{3}{|c|}{$\begin{array}{c}\text { Expectation of } \\
\text { negative evaluation }\end{array}$} & \multicolumn{3}{|c|}{ BMI } \\
\hline Worry about imperfection & -.13 & \multicolumn{3}{|c|}{.127} & \multicolumn{3}{|c|}{-.107} \\
\hline Hope for perfection & $-.31 * *$ & \multicolumn{3}{|c|}{$.62 *$} & \multicolumn{3}{|c|}{.029} \\
\hline BMI (body mass index) & $-.180 *$ & \multicolumn{3}{|c|}{$.144 *$} & \multicolumn{3}{|c|}{1} \\
\hline \multicolumn{2}{|c|}{$\begin{array}{l}\text { Correlation analysis results for the } \\
\text { relationship between the participants' } \\
\text { Physical Appearance Perfectionism and } \\
\text { Social Physique Anxiety subscale scores } \\
\text { showed a strong negative correlation between } \\
\text { hope for perfection (a subscale of PAPS) and } \\
\text { comfort with appearance (a subscale of } \\
\text { SPAS), while a positive relationship was } \\
\text { observed between the former and expectation } \\
\text { of negative evaluation (a subscale of SPAS). } \\
\text { In addition, there was a negative correlation } \\
\text { between the participants' BMI scores and }\end{array}$} & \multicolumn{6}{|c|}{$\begin{array}{l}\text { comfort with appearance }(\mathrm{r}=-.180, p<.05) \\
\text { and a positive }(\mathrm{r}=.144, p<.05) \text { significant } \\
\text { relationship between BMI scores and } \\
\text { expectation of negative evaluation. } \\
\text { To resolve another issue related to this study, } \\
\text { the Physical Appearance Perfectionism and } \\
\text { Social Physique Anxiety scores of the } \\
\text { participants were compared based on whether } \\
\text { they engaged in exercise. The t-test results of } \\
\text { that analysis are given in Table } 4 \text {. }\end{array}$} \\
\hline \multicolumn{8}{|c|}{$\begin{array}{l}\text { Table 4. t-Test Results of Comparison of PAPS and SPAS Scores of the Participants by Exercise } \\
\text { Status }\end{array}$} \\
\hline \multicolumn{2}{|l|}{ Subscales } & Status & $\mathbf{n}$ & $\mathbf{X}$ & SS & $\mathbf{t}$ & $p$ \\
\hline \multirow{2}{*}{ Worry about imperfection } & & & 124 & 2.92 & .42 & \multirow{2}{*}{-.527} & \multirow{2}{*}{.599} \\
\hline & & & 67 & 2.95 & .48 & & \\
\hline \multirow{2}{*}{ Hope for perfection } & & & 124 & 2.65 & .54 & \multirow{2}{*}{-.898} & \multirow{2}{*}{.370} \\
\hline & & & 67 & 2.72 & .47 & & \\
\hline \multirow{2}{*}{ Comfort with appearance } & & & 124 & 4.37 & .97 & \multirow{2}{*}{2.002} & \multirow{2}{*}{$.047^{*}$} \\
\hline & $\mathrm{N}$ & & 67 & 4.04 & 1.27 & & \\
\hline \multirow{2}{*}{\multicolumn{2}{|c|}{ Expectation of negative evaluation }} & & 124 & 2.41 & .78 & \multirow{2}{*}{-142} & \multirow{2}{*}{.888} \\
\hline & & & 67 & 2.42 & .72 & & \\
\hline
\end{tabular}

$* p<.05$

As shown by the t-test results in Table 4, the average scores of the Physical Appearance comfortable with their physical appearance $(\mathrm{t}$ $=2.002 ; p<.05$ ).

Perfectionism subscales did not differ according to exercise status, whereas the Social Physique Anxiety subscale scores were found to differ in favor of exercisers. The analysis revealed a significant difference in favor of exercisers in the "comfort with appearance" subscale of SPAS, as participants who engaged in exercise were more 
Çepikkurt, F., Ayaz, Y. S., Ada, E. N., Kızıldağ Kale, E. (2020). Investigation of Physical Appearance Perfectionism and Social-Physical Anxiety in College Students. International Journal of Recreation and Sports Science, 4(1), 55-64. Doi.org/10.46463/ijrss.787026

\section{DISCUSSION}

This study was conducted to determine the perfectionism of university students as to their physical appearance, their concerns regarding their social appearance, and to reveal the relationship between them.

The results of our analysis revealed that perfectionism in physical appearance and social physique anxiety were similar for the female and male participants (Table 2). The relevant findings obtained in this study support those of certain earlier studies while contradicting others. In a number of studies examining gender differences in anxiety regarding social appearance, women were found to experience more intense anxiety than men (Hagger and Stevenson, 2010; Eklund, Kelley and Wilson, 1997; Frederick and Morrison, 1996; Haase and Prapavessis, 1998; Kruisselbrink, Dodge, Swanburg, MacLeod, 2004; Lantz, Hardy, Ainsworth, 1997; Mack, Strong, Kowalski, Crocker, 2007). The expected result in many studies was that social appearance anxiety would be higher in women than in men. For example, Labunskaya and Pogontseva (2018) stated that women with different levels of visual perfectionism exhibit different levels of satisfaction and anxiety concerning their appearance, and that women with high perfectionism show high satisfaction with and interest in their appearance, but that this situation was not valid for men. They emphasized that this difference between men and women regarding appearance perfectionism further leads to differences in individuals' attitudes towards their appearance, satisfaction, interests, and tendencies towards change. Another study reported that the relationship between social appearance anxiety and problematic eating behaviors or compulsive exercise was more intense in women than in men (Hausenblas and Fallon, 2002). However, the results of some studies have shown greater social appearance anxiety on the part of men than women (Birchwood et al. 2006; Doğan, 2009; Alemdar and Öncü, 2015). Contrary to the examples given above and to expectations, the present study found similar levels of physical appearance perfectionism and social appearance anxiety in female and male university students. Some previous studies have reported no significant differences in social appearance anxiety based on gender (Fayhout et al.2005; Yang and Stoeber, 2012; Yang et al. 2017). Yang and Stoeber (2012) and Yang et al. (2017) revealed that female and male students' perfectionism and social appearance anxiety scores did not differ, but noted that there was a positive relationship between these two variables.

The similarity between the perfectionism and social appearance concerns of the male and female participants in the present study can be explained by a number of factors. McArthur, Holberd and Pena (2005) stated that men desire a muscular body with a minimum amount of fat instead of the thinnest physique possible, and not having a muscular and lean body does not represent a source of concern for them. For women, however, having an overweight and disproportionate body constitutes a source of great concern. Nonetheless, although the ideal body perceptions of the two genders are different, failure to attain these ideal forms will lead to similar results.

The secondary objective of this study was to investigate the relationship between physical appearance perfectionism and social appearance anxiety. The results of the analysis conducted for this purpose showed a negative relationship between the "hope for perfection" subscale of physical appearance perfectionism and the "comfort with appearance" subscale of social physique anxiety. A positive relationship was found between the "hope for perfection" subscale and the "expectation of negative evaluation" subscale. These results suggest that individuals hoping to achieve perfection and striving hard to do so feel greater discomfort due to their appearance and experience more intense concerns that they will be evaluated negatively. The findings obtained in the present study are important in that they support the results of studies showing physical appearance perfectionism to 
be associated with eating disorders, negative weight control behaviors, and concerns about body image (Yang and Stoeber, 2012), to increase social appearance anxiety (Shang and Yang, 2013), trigger body dissatisfaction as well as the desire to lose weight (Yang et al., 2017), and reduce body satisfaction and selfconfidence (Shang and Yang, 2014).

In studies where field-specific perfectionism scales could not be used, clear evidence has been found of an association between negative subscales of perfectionism (for example, being concerned with mistakes, doubting one's actions, etc.) and negative body perception and body dissatisfaction (Hewitt et al. 1995; Donovan, Chew, and Penny, 2014; Wade and Tiggemann, 2013; Boone, Soenens and Braet, 2011; Boone, Soenens and Luyten, 2014). In their study of male university students, Grammas and Schwartz (2009) reported that social-induced perfectionism was associated with body dissatisfaction arising from height, weight, and muscle structure in their study. Sweeney and Fingerhut (2013) determined the existence of a relationship between maladaptive perfectionism dimensions and body dissatisfaction in their study on pregnant women.

Physical appearance perfectionism can affect a person's attitudes towards their appearance, their self-esteem, positive and negative perceptions of their bodies, the enjoyment they derive from their appearance and life in general, and many health-related conditions (Feragen and Stock, 2018; Varlashkina and Dementii, 2010; Shalygina and Kholmogorova, 2015). Therefore, due to their self-confidence, individuals with positive perfectionist attitudes regarding their physical appearance are expected to have an advantage in setting clear goals for themselves, nurturing positive thoughts, loving themselves, communicating comfortably, expressing themselves, and controlling their emotions. Individuals exhibiting negative perfectionism related to their physical appearance are likely to experience negative emotions, especially social appearance anxiety, acquire negative perceptions about their bodies, and adopt negative behaviors (such as eating disorders, compulsive exercise, uncontrolled drug use) as a result of these negative feelings.

Another finding of this study was that university students who exercised regularly were more comfortable with their appearance (Table 4). The participants' body mass index values were negatively related to comfort with appearance and positively associated with expectation of negative evaluation. As is known, how individuals perceive their bodies and concerns about their appearance may play either preventive or motivating roles with regard to participation in exercise. In the present study, participants who exercised had lower BMI and a positive relationship was found between BMI and social physique anxiety, both findings being consistent with those obtained in previous studies (e.g., Tiggemann, 2001; Hausenblas and Fallon, 2002; Mülazımoğlu, Kirazcı, and Aşçı, 2002; Alemdar and Öncü, 2015; Yalçın and Ayhan, 2020). Yalçın and Ayhan (2020) concluded that physical appearance perfectionism and the psychological well-being of women participating in athletic activities had a significant effect on their inner and outer selfconfidence. Tiggemann (2001) reported that individuals who participate in sports experienced less dissatisfaction with their bodies, and Arabac1, Öztürk Kuter, and Doğan (2008) found a positive relationship between social physique anxiety and body fat percentage and BMI. In a study conducted with university students to examine the effects of different types of exercise on social physique anxiety, Özdemir et al. (2010) showed that the anxiety levels of individuals who participated in a 10-week Swiss ball exercise program significantly decreased.

According to our findings, engaging in physical activity is expected to positively reduce social physique anxiety, and individuals with low body mass index may experience less anxiety regarding their appearance. Regular exercise increases selfesteem and self-efficacy, while body satisfaction increases with self-confidence and pleasure hormones are released during and after exercise. The development of body 
Çepikkurt, F., Ayaz, Y. S., Ada, E. N., Kızıldağ Kale, E. (2020). Investigation of Physical Appearance Perfectionism and Social-Physical Anxiety in College Students. International Journal of Recreation and Sports Science, 4(1), 55-64. Doi.org/10.46463/ijrss.787026

consciousness and the change in focus of attention stimulated by physical activity then enables the individual to distance him/herself from anxieties and negative thoughts. Taking these results into account allows us to interpret the findings obtained in this study more clearly.

\section{REFERENCES}

Alemdar, S. \& Öncü, E. (2015). Öğretmen Adaylarının Fiziksel Aktiviteye Katılım ve Sosyal Görünüş Kaygılarının İncelenmesi. International Journal of Science Culture and Sport (IntJSCS), 3, 287-300.

Arabacı, R., Öztürk Kuter, F. \& Doğan, A. (2008). Sosyal fizik kaygı ve bazı fiziksel uygunluk özellikler arasındaki ilişkinin araştırılması. E-Journal of New World Sciences Academy Health Sciences, 3 (4), 185-193.

Birchwood, M., Trower, P., Brunet, K., Gilbert, P., Iqbal, Z., \& Jacson, C. (2006). Social anxiety and the shame of psychosis: A study in first episode psychosis. Behaviour Research Therapy, 52: 55-68.

Boone, L., Soenens, B., \& Braet, C. (2011). Perfectionism, body dissatisfaction, and bulimic symptoms: The intervening role of perceived pressure to be thin and thin ideal internalization. Journal of Social and Clinical Psychology, 30, 1043-1068.

Boone, L., Soenens, B., \& Luyten, P. (2014). When or why does perfectionism translate into eating disorder pathology? A longitudinal examination o the moderating and mediating role of body dissatisfaction. Journal of Abnormal Psychology, 123, 412418.

Burns, D. D. (1980). The perfectionist's script for self-defeat. Psychology Today, 14(6), 3452.

Cash, T. F. (2002). Cognitive-behavioral perspectives on body image. In T. F. Cash \& T.Pruzinsky (Eds.),Body image: A handbook of theory, research and clinical practice(pp.38-46). New York: Guilford Press.

Çepikkurt, F. \& Yazgan İnanç, B. (2012). Determining the Role of Perfectionism and Achievement Goals for Competitive Anxiety of College Handball Players, SPORMETRE Beden Eğitimi ve Spor Bilimleri Dergisi, 10(2) 43-51.
Doğan, T. (2009). Bilişsel ve kendini değerlendirme süreçlerinin sosyal anksiyete açısından incelenmesi. Yayımlanmamış Doktora Tezi. Sakarya Üniversitesi Sosyal Bilimler Enstitüsü, Sakarya.

Doğan, T. (2010) Sosyal görünüş kaygısı ölçeğinin Türkçe uyarlaması: Geçerlik ve güvenirlik çalışması. Hacettepe Üniversitesi Eğitim Fakültesi Dergisi, 39:151- 159.

Donovan, C. L., Chew, D. \& Penny, R. (2014). Perfecting weight restriction: The moderating influence of body dissatisfaction on the relationship between perfectionism and weight control practices. Behavior Change, 31, 189-204.

Eklund, R.C., Kelley, B., \& Wilson, P. (1997). The social physique anxiety scale: Men, women, and the effects of modifying item 2. Journal of Sport and Exercise Psychology, 19, 188-196.

Faytout, M., Tignol, J., Swendsen, J., Grabot, D., \& Aouizerate, B., (2005). Social phobia, fear of negative evaluation and harm avoidance. Europen Psychiatry, 21:1-5.

Feragen K. B. \& Stock N. M. (2018). Factors affecting subjective appearance evaluations among patients with congenital craniofacial conditions: An application of Cash's cognitive-behavioral model of body image development, Body Image, 24, 124- 136.

Frederick, C.M., \& Morrison, C.F. (1996). Social physique anxiety: Personality constructs, motivations, exercise attitudes, and behaviors. Perceptual and Motor Skills, 82, 963-972.

Frost, R. O., Marten, P., Lahart, C. \& Rosenblate, R. (1990). The Dimensional of perfectionism. Cognitive Therapy and Research, 14 (5), 449-468.

Grammas, D. L., \& Schwartz, J. P. (2009). Internalization of messages from society and perfectionism as predictors of male body image. Body Image, 6, 31-36

Haase, A.M., \& Prapavessis, H. (2001). Social physique anxiety and eating attitudes in female athletic and non-athletic groups. Journal of Science and Medicine in Sport, 4, 396-405.

Hart, E. A., Leary, M. \& Rejeski, W. J. (1989). The Measurement of Social Physique Anxiety, Journal of Sport \& Exercise Psychology 11(1), 94-104

Hart, T. A., Palyo, S. A., Fresco, D. M., Holle, C., \& Heimberg, R. G. (2008). Development 
Çepikkurt, F., Ayaz, Y. S., Ada, E. N., Kızıldağ Kale, E. (2020). Investigation of Physical Appearance Perfectionism and Social-Physical Anxiety in College Students. International Journal of Recreation and Sports Science, 4(1), 55-64. Doi.org/10.46463/ijrss.787026

and examination of the social appearance anxiety scale. Assessment, 15, 48.

Hausenblas, H.A. \& Fallon, E.A., (2002). Relationship among body image, exercise behavior, and exercise dependence symptoms. International Journal of Eating Disorders, 32(2), 179-85.

Hewitt, P. L., \& Flett, G. L. (1991). Perfectionism in the self and social contexts: conceptualization, assessment, and association with psychopathology. Journal of Personality and Social Psychology, 60, 456-470.

Hewitt, P. L., Flett, G. L. \& Ediger, B. A. (1995). Perfectionism traits and perfectionistic self-presentation in eating disorder attitudes, characteristics, and symptoms. International Journal of Eating Disorders, 18 (4), 317-326.

Kolsallayan, A. (2017). Egzersiz katılımcılarının fiziksel görünüş mükemmeliyetçiliği ve psikolojik iyi oluş düzeylerinin egzersize katılım güdüsüne etkisi. Yüksek Lisans Tezi, Ege Üniversitesi, Sağlık Bilimleri Enstitüsü, Sporda Psiko-Sosyal Alanlar Anabilim Dalı, İzmir.

Kruisselbrink, D.L., Dodge, A.M., Swanburg, S.L., \& MacLeod, A.L. (2004). Influence of same-sex and mixed-sex exercise settings on the social physique anxiety of males and females. Journal of Sport and Exercise Psychology, 26, 616-622.

Labunskaya, V. \& Pogontseva, D. (2018). Appearance perfectionism, satisfaction and concern with appearance as factors of lookism accessibility in everyday interaction. Section Psychology\& Psychiatry. 5th SGEM International Multidisciplinary Scientific Conferences on SOCIAL SCIENCES and ARTS.

Lantz, C.D., Hardy, C.J., \& Ainsworth, B.E. (1997). Social physique anxiety and perceived exercise behavior. Journal of Sport Behavior, 20, 83-93.

Leit, R. A., Gray, J. J. \& Pope, H. G. (2002). The medai's representation of ideal male body. A cause for muscle dysmorphia? International Journal of Eating Disorders, 31, 334-338.

Mack, D.E., Strong, H.A., Kowalski, K.C., \& Crocker, P.R.E. (2007). Does friendship matter? An examination of social physique anxiety in adolescence. Journal of Applied Social Psychology, 37, 1248-1264.
McArthur, L.H., Holbert, D., \& Pena, M. (2005). An exploration of the attitudinal and perceptual dimensions of body image among male and female adolescents from six Latin American cities. Adolescence, 40, 801-816.

Mülazımoğlu, Ö, Kirazcı, S. \& Aşçı, F.H., (2002) Sporcu ve sporcu olmayan bayanların sosyal fizik kayg1 ve beden imgesinden hoşnut olma düzeyleri. 7. Spor Bilimleri Kongresi, 27-29 Ekim 2002, KemerANTALYA.

Mülazımoğlu-Ballı, Ö. \& Aşçı, H. (2006). Sosyal fizik kaygı envanteri'nin güvenirlik ve geçerlik çalışması. Hacettepe Journal of Sport Sciences, 17 (1), 11-19.

Özdemir, R. A., Çuğ, M. \& Çelik, Ö. (2010). Genç yetişkin üniversite öğrencilerinde farkl1 türde egzersiz uygulamalarının sosyal fizik kayg1 düzeyine etkisi. Hacettepe Journal of Sport Sciences, 21 (2), 60-70.

Pope, H. G., Olivardia, R., Gruber, A., \& Borowiecki, J. (1999). Evolving ideals of malebody image as seen through action toys.International Journal of Eating Disorders, 26,65-72.

Pope, H. G., Gruher, A. J., Magweth, B., Bureau, b., de Col, C., Jouvent, K. et al. (2000). Body image perfection among men in three countries. American Journal of Psychiatry, 157, 1297-1301.

Ricciardelli, L. A., \& McCabe, M. P. (2004). A biopsychosocial model of disordered eatingand the pursuit of muscularity in adolescent boys. Psychological Bulletin, 130,179-205.

Shalygina O.V. \& Kholmogorova A.B. (2015). "Body orientation" of the contemporary culture and it's influence on the children's, adolescents' and youth's health, Psychology and Psychotherapy Counseling, 4(88), 36-68.

Shang, Z., \& Yang, H. (2013). Mediation effect of appearance stress on relationship between perfectionism and mental health. Chinese Journal of Public Health, 29, 1799-1802.

Shang, Z., \& Yang, H. (2014). Mediation effect of appearance self-esteem on relationship between perfectionism and mental health. Chinese Journal of Public Health, 30, 769772 .

Snell, W. E., Jr., Overbey, G. A., \& Brewer, A. L. (2005). Parenting perfectionism and the 
Çepikkurt, F., Ayaz, Y. S., Ada, E. N., Kızıldağ Kale, E. (2020). Investigation of Physical Appearance Perfectionism and Social-Physical Anxiety in College Students. International Journal of Recreation and Sports Science, 4(1), 55-64. Doi.org/10.46463/ijrss.787026

parenting role. Personality and Individual Differences, 39, 613-624.

Slaney, R. B., Rice, K. G., Mobley, M., Trippi, J. \& Ashby, J. (2001). The Revised almost perfect scale. Measurement and Evaluation in Counseling and Development, 34, 130145.

Stoeber, J., Harvey, L. N., Almeida, I., \& Lyons, E. (2013). Multidimensional sexual perfectionism. Archives of Sexual Behavior, 42, 1593-1604.

Sweeney, A. C., \& Fingerhut, R. (2013). Examining relationships between body dissatisfaction, maladaptive perfectionism, and postpartum depression symptoms. JOGNN, 42, 551-561.

Thompson, J. K., \& Cafri, G. (Eds.). (2007).The muscular ideal: Psychological, social, andmedical perspectives. Washington, DC: American Psychological Association.

Tiggemann, M. (2002). Media influences on body image development. In T. F. Cash \& T.Pruzinsky (Eds.),Body image: A handbook of theory, research and clinical practice(pp.91-98). New York: Guilford Press.

Yang, H., \& Stoeber, J. (2012). The Physical Appearance Perfectionism Scale: Development and preliminary validation. Journal of Psychopathology and Behavioral Assessment, 34, 69-83.

Yang, H., Yang, Y., Xu, L., Wu, Oianwen, Xu, J. Weng, E., Wang, K. Cai, S. (2017). The relation of physical appearance perfectionşsm with body dissatisfaction among school students 9-18 years of age. Personality and Individual Differences, 116, 399-404. 